\title{
Hyseq-Variagenics merger signals end of the line
}

The announcement on November 11, 2002 that genomics companies Variagenics (Cambridge, MA) and Hyseq (Sunnyvale, CA) were to merge came as no shock to anyone who had followed either company. Both merging partners had developed interesting technologies and completed initial public offerings, but neither had managed to build substantial development momentum either internally or through outside collaboration. The lesson for both new and established companies, it seems, is that it is necessary but not sufficient to cash in on investor enthusiasm for a given area of technology. Companies in genomics and elsewhere must not only project a clear value-creating development path but also be seen to follow it.

Variagenics and Hyseq maintain that the merger was a strategic move that brings together the cash and the molecules that a company needs to proceed in drug development. In essence, the stock-for-stock deal worth a nominal \$55.9 million creates a company that has one drug in phase 1 trials-Hyseq's next-generation thrombolytic, Alfimerprase-and enough cash (over \$60 million, largely from Variagenics) to finance $R \& D$ activities through to the end of 2004. The merged entity also has a series of early-stage preclinical biotherapeutics from Hyseq's gene-patenting activities, and programs in cancer diagnosis, SNP analysis, and pharmacogenomics from Variagenics.

Some commentators were scathing about the merger, however. One genomics CEO, who did not wish to be named, believed that the deal had arisen out of desperation: "This merger simply adds one company that has lost its way to a company that never had a way." He considers that the Hyseq-Variagenics deal is far from typical of those in genomics in that it does not move either company significantly closer to having a drug-development capability.

Undoubtedly both companies had been actively looking for solutions to their individual difficulties. According to Rick Shea, Variagenics CFO and COO, the company has been looking around at its strategic alternatives for over a year. He says the company considered alliances, mergers into pharmaceutical groups as the junior partners, and acquisitions of early-stage companies. "We talked with a lot of companies—at least 60."

Variagenics has undertaken stringent cost-cutting measures this year, most notably the termination of its NuCleave genotyping platform product to reduce cash burn by $\$ 4$ million a quarter. This also cut overall revenues by approximately $60 \%$. But it did allow a reduction in head count of 44 , or $30 \%$ of the workforce, particularly in the area of high-throughput DNA sequencing. To add to the pressure on the company, Variagenics received a de-listing notice from Nasdaq at the end of October because its common stock price had fallen below $\$ 1.00$ at the end of September and for most of October.

The main problem for Variagenics, though, was that it simply failed to secure enough deals with pharmaceutical companies in pharmacogenomics. Although the company does now have a collaboration with Novartis (Basel, Switzerland) on its prostate cancer drug, Gleevec, the expectations at the company's IPO back in July 2000 were that the company could secure one big deal per quarter. That never happened. Shea believes that Variagenics may have been a victim of its early arrival in pharmacogenomics. "The received wisdom is that pharmaceutical companies will pay for unproven technology in drug discovery," he says, "but in drug development they want to buy services." He hopes that by taking Hyseq's clinical program forward, the newly merged company may be able to provide the essential commercial proof of concept.

Hyseq had its own difficulties, most prominently in regard to cash. Despite two bridging private rounds of funding since August 2001, Hyseq came into the merger with just over $\$ 4$ million in cash-enough for a month and half at the sort of burn rate the company had been used to in the first 9 months of the year. The company had lost nearly 80 employees $(40 \%)$ over the year, largely in the area of agricultural gene discovery when its collaboration with BASF Plant Science was terminated.

However, one analyst says the merger with Variagenics is an expensive way to raise cash. This is clear from a comparison with two earlier Hyseq private placements raised at $\$ 7.00$ per share (August 2001) and $\$ 4.20$ per share (April 2002). By November, though, Hyseq's stock price had fallen to around \$1.20-1.40 a share and, in essence, Hyseq had to sacrifice $60 \%$ of the company to merge with Variagenics and its cash pile.

Both Variagenics and Hyseq had originally followed a service-data provision business model, an approach that has proved unsustainable even for well-funded companies such as Celera (Rockville, MD) and InCyte (Palo Alto, CA). "These days," says Robin Jackman, VP for corporate development at Sequenom (San Diego, CA), "over the long term it is difficult to be a purely service-based business in genomics. Eventually you need to be either a systems-based business that sells instrumentation [and consumables], or you need to develop drugs." Sequenom has been developing mass spectrometry-based high-throughput DNA analysis technology but has more recently expanded its approach through two acquisitions. It bought Gemini Genomics (Cambridge, UK) in September 2001 "for its population cohorts and for its $\$ 75$ million in cash." This September it bought a small San Diego company, Axiom Biotechnologies, that was running out of cash. That purchase added a small drug-development capability to Sequenom. Jackman sees significant merit for genomics companies in making the right mergers. "You are never going to be able to buy a shrink-wrapped, ready-to-go acquisition candidate. There will always be some warts," he says, "The question is, how much money and time would it take to build what you are acquiring, and is the headache of restructuring worth it."

Nick McCooke, CEO of Solexa (Cambridge, UK), believes that the lesson younger companies should take from Variagenics and Hyseq is the need to chart a clear path to value creation, and then show that you can follow that path. Solexa was established in 1998 and is developing a whole-genome resequencing technology based on arrays containing millions of different molecules of DNA. "I think we do have to fight harder to demonstrate value. It's a more sceptical world now," he says. "In 2000, you only had to have 'genomics' in the name and you could raise money. Now you have to be very clear indeed about what you are doing, and why, and how this is going to create value in the company."

McCooke considers that the greater scrutiny that genomics companies are undergoing these days is a good thing. "When there is plenty of money sloshing around, investors-and perhaps the companies themselves-don't see the black clouds," he says. In more realistic times, both pay more attention to the business plan. "That's how business normally is. Good companies are still finding private investment," he argues. "Perhaps the worst place to be is a small-cap public company." Variagenics and Hyseq might agree.

John Hodgson, Cambridge, UK 